\title{
Christian Apologists AND THE ANTONINE EMPERORS \\ Apologetas CRISTIANOS Y LOS \\ EMPERADORES ANTONINOS
}

Christopher P. JONES

UNIVERSITY OF HARVARD

CJONES@FAS.HARVARD.EDU

\begin{abstract}
The Antonine period from Hadrian onwards sees the beginning of a Christian literature of "apology," more precisely of defense and justification of the new religion. These defenses sometimes take the form of attacks on "pagan" cults or on Judaism. The Christians begin to represent their religion as a philosophy, worthy of consideration beside the traditional philosophies of the Graeco-Roman world. At the same time Christians are still persecuted, and imperial policy towards them, as expressed in the form of imperial edicts or implicitly by
\end{abstract}

\section{RESUMEN}

El periodo Antonino a partir de Adriano ve el comienzo de una literatura cristiana de "apología", más precisamente de defensa y justificación de la nueva religión. Esas defensas a veces toman la forma de ataques a los cultos "paganos" o al Judaísmo. Los cristianos comienzan a representar su religión como una filosofía, digna de consideración junto a las filosofías tradicionales del mundo Greco-Romano. Al mismo tiempo, la persecución de los cristianos y la política imperial hacia ellos continúan, expresadas a través de edictos imperiales o implícita- 
the practice of governors, continues, even if unevenly. There is a sharp upturn of persecution in the reign of Marcus Aurelius, perhaps exacerbated by the internal and external setbacks of the reign mente en las práctica de los gobernadores, aunque en manera desigual. Hay un repunte agudo de la persecución en el reinado de Marco Aurelio, quizás exhacerbado por los reveses internos y externos del reino.

\section{KEYWORDS}

Apology, martyrdom, Marcus Aurelius, persecution, philosophy

\section{Palabras Clave}

Apología, martirio, Marco Aurelio, persecución, filosofía 
The Antonine period saw the beginning of a new kind of Christian literature. Hitherto Christians had written for their own community, even though the four canonical evangelists had perhaps written with an eye to non-Christian readers. But with the reign of Hadrian there emerges a literary genre that is directed outwards, and is customarily called "apologetic", though not all the forms it takes are defensive or explanatory. Sometimes it is an address to the reigning emperor, similar to the petitions in which subjects commonly approached authority: this is the approach of Aristides, Justin, and Athenagoras. At other times it is mainly a refutation of Jewish objections or an attack on paganism: thus Justin in his Dialog with Trypho and Tatian in his Speech to the Greeks. Athenagoras' On the Resurrection is different from all of these, a learned, semi-scientific treatise justifying one of Christianity's most difficult tenets, that of the eternal life of the faithful.

About the same time there also emerges another kind of Christian literature - the literature of martyrdom, of which this period sees the first extant examples (though the letters of Ignatius under Trajan are a precursor): of Polycarp under Pius, of Lugdunum under Marcus, of the Scillitan martyrs and of the Roman Apollonius under Commodus. ${ }^{1}$ There also appears in non-Christian literature the first attempts to confront and refute the new faith, notably in Celsus' True Word.

In a volume on the policy of the Antonine emperors towards the variety of religions in their empire, it is appropriate to consider how far these literary developments are part of Christianity's internal growth and how far they are due to external circumstances. The term "policy" implies something less than the fixed and delib-

1. I follow the traditional dates for these martyrdoms, despite the lateness of the extant narratives and the divergences between them: see now Rébillard, 2017. Similarly, I use "persecution" to denote both persecution arising from local hostility and persecution promoted or permitted by higher authority: the two often went together. 
erate long-term policies of modern governments towards religious groups, whether segments of their own population or outsiders friendly or hostile. Fergus Millar has described a petition-and-response model of the emperors' relation with their subjects, but this need not imply a mere reaction to stimuli: a pattern consistently maintained - for example, a series of responses encouraging benefactors to use their generosity for buildings rather than for transitory entertainments - can amount to a policy. ${ }^{2}$ Moreover, emperors are also citizens writ large, and can make social choices that echo the choices of the upper classes or "elites". Nor should we discount the effect of pressure from below - not merely the petitions and addresses of literate subjects, but the pressures that could be brought by the less educated through coordinated "shouts" (boai), which are not the same as "acclamations" (euphêmiai, epiboêseis), through riots, even through rebellion, as in Achaea under Pius.

After these preliminary clarifications, in what follows I will first give a rapid overview of the relations between Christians and the second-century emperors, from Trajan to Commodus, together with the Christian writings that are usually our best source. After that overview, I shall suggest some factors that influenced the changes that can be discerned in imperial policy over this same period.

The reign of Trajan is remembered for the exchange between the emperor and Pliny the Younger on the treatment of the Christians of Pontus about the year $110{ }^{3}$ Pliny's uncertainty as to how to proceed suggests that he had received no imperial instructions (mandata) on the subject, and if Trajan's reply can be said to reveal a policy, it is less one of toleration of Christianity than of maintaining the due procedures of Roman law, especially after the perceived abuses of Domitian's reign. Pliny has done well, the emperor says, to execute those Christians who refuse to apostatize, and in future he must send to Rome any who are Roman citizens and have been lawfully accused. We have the letters of a Christian bishop sent to Rome in just this way, Ignatius of Antioch, who may have been a citizen, and his expectation of martyrdom was certainly fulfilled. ${ }^{4}$

If the rescript of Hadrian to Minicius Fundanus, a friend to both Pliny and Plutarch, is authentic, or at least if the wording preserved by Eusebius is close to the original, the emperor ruled that those accusing Christians must prove them to have contravened "the laws", and that defendants must be allowed to make their defense,

2. Millar, 1977; Coleman, 2008, with further bibliography.

3. Plin., Ep. 10, 96-97.

4. Quasten, 1950, pp. 63-76; Paulsen, 1996, pp. 933-994; Camelot, 1998. I follow the usually accepted date in the reign of Trajan. 
whereas Trajan had merely ruled that charges against Christians must be brought openly and not anonymously. But "the laws" was a vague term, allowing magistrates ample scope for punishment, ${ }^{5}$ and this amounts only to a slight change from the course laid down by Trajan to Pliny. Another clause in Hadrian's rescript was more favorable - his ruling that governors should not listen to "requests or mere shouts"

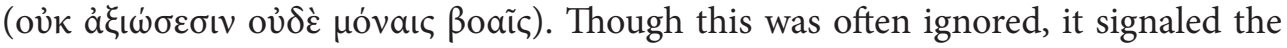
emperor's awareness of a danger to which Christians were constantly exposed. ${ }^{6}$

Hadrian's policy of moderate toleration seems to find its echo in the emergence of a first generation of apologists. Very little is known of Quadratus, whom Eusebius mentions for his treatise addressed to Hadrian "in defense of our religion, because some wicked men were trying to trouble our people." The Apology of Aristides of Athens, also addressed to Hadrian, is better represented, since part of it survives on papyrus, and another part was incorporated in a Christian romance, The Tale of Barlaam and Joseph. An oddity of Aristides' approach is the way he describes the Christian community as if he himself were an outsider: Christians are "them," not "us," and he attributes his knowledge of them to his reading of "their books." It is unclear whether he adopts this strategy to give his arguments an air of objectivity and thus make them more persuasive, or whether he thought it unsafe to make open confession of his beliefs, though Quadratus had no such scruple. ${ }^{8}$

Antoninus Pius shared none of his predecessor's taste for travel, for strange and exotic knowledge, or for Egyptian religion and antiquities, and he seems to have had little personal interest in Greek paideia, though he provided a proper upper-class education for his adoptive sons, Marcus Aurelius and Lucius Verus. Pius was more concerned to project an image of legitimacy and continuity. His agnomen Pius advertised his unbroken succession from Hadrian; images and cult proclaimed his perfect marriage with Faustina (not marred in Roman eyes by his taking a concubine after her death), and the duly arranged succession of Marcus, with Lucius kept in reserve. ${ }^{9}$

Insofar as Pius had an observable policy toward Christianity, it has to be inferred from one highly disputed document - a rescript that comes down in three versions. One of these is preserved only in manuscripts of Justin Martyr, which at-

5. On the scope allowed to provincial magistrates in the administration of justice, Sainte-Croix, 1963, pp. 6-38, reprinted in de Sainte-Croix, Whitby and Streeter, 2006.

6. Hadrian's letter: Euseb., Hist. eccl. 4, 9; Bardy, 1952.

7. Euseb., Hist. eccl. IV 3, 1-2; Quasten, 1950, pp. 190-191; "Quadratus," The Oxford Dictionary of the Christian Church, $3^{\text {rd }}$ ed., Oxford, 1997, p. 1354.

8. Euseb., Hist. eccl. IV 3, 3; Quasten, 1950, pp. 190-195; Pouderon et al., 2003.

9. Marriage: Weiss, 2008, pp. 1-45. Succession: Jones, 2013, pp. 49-52. 
tributes it to Pius and Marcus jointly at the end of Pius' reign; a second is preserved in Eusebius, attributing it to Marcus alone; and Rufinus' Latin translation, which closely follows Eusebius, constitutes a third. I have argued that the first of these three is the most likely to preserve elements of the original, and that it can be used to reconstruct an essentially authentic text. If that is right, it shows that Pius wrote to the provincial council of Asia ordering that Christians not be persecuted merely because of the panic caused by a recent series of earthquakes; invoking Hadrian's precedent, he orders that there shall be no mob justice, and that those bringing charges of Christianity must show that the accused is conspiring against the interests of the empire. This is narrower ground for accusation than Hadrian's vague "against the laws," and to this extent Pius may have somewhat relaxed the conditions under which Christians could practice their religion. ${ }^{10}$

Yet the reign of Pius did not introduce a pax Ecclesiae. There were trials of Christians in Rome under the urban prefect, Lollius Urbicus, who held office from 146 to 161. ${ }^{11}$ The end of the reign is probably the time of the first extant martyr-acts, those of bishop Polycarp and other Christians of Smyrna. In this account, the attacks on the Christian community come not from above but from below, as in Pontus under Pliny. The Smyrnean populace puts pressure on the governor, and there is no sign of the emperor's intervention or even knowledge, as there is in the martyrdoms of Lugdunum twenty years later. ${ }^{12}$

About the time of the martyrdom of Polycarp, a future martyr, Justin, wrote his Apology, which survives in two parts. The main part, called the Second Apology in the archetype, addresses Pius, Marcus, Lucius, and the senate and people of Rome. What the archetype calls the First Apology is sometimes regarded as the ending of the first, though the opening lines suggest that it belongs to the reign of Marcus. In the Second Apology Justin offers a general defense of Christian doctrine, acknowledging that there have been recent persecutions of Christians, but giving no details. His narrative of how he tested other philosophies before arriving at his destination is not original: what is original is that he arrived at the "philosophy" of the Christians. He now undertakes to expound Christian doctrines to his imperial hearers, of whom he

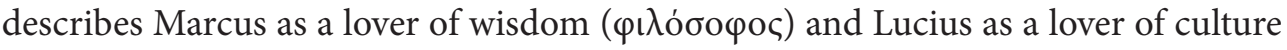

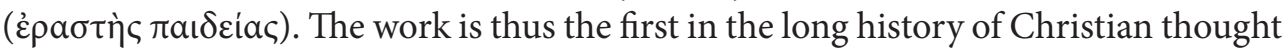

10. Letter of Pius: Euseb., Hist. eccl. IV 13; for the version transmitted in manuscripts of Justin, Bardy, 1952, p. 178, n. 5. For this argument: Jones, 2018.

11. Justin, II Apol. 2, in Munier, 2006. Lollius Urbicus: Groag, Stein et al., 1933-2015, L 327.

12. Martyrdom of Polycarp: Rébillard, 2017, pp. 108-147. On the date: Groag, Stein et al., 1933-2015, S 883 .

ARYS, 16, 2018 [333-345] ISSN 1575-166x 
to present the faith as a "philosophy," and one superior to long-established schools such as Platonism and Stoicism. ${ }^{13}$ This claim moved Christianity into a cultural arena in which it needed both to attract adherents by argumentative rigor and to meet rival philosophies on their own ground. I shall return to this "philosophization" of Christianity as part of what sharpened the contrast with Judaism, and as a reason for the rise of apologetic as a new form of Christian literature. ${ }^{14}$

While making a philosophic defense of his beliefs, Justin is also well aware of the continuance of persecution. Those who are accused of being Christians, he argues, should be punished if they have committed crimes, but if they are proved guilty their guilt should not be used to condemn Christians in the mass. He anticipates opposition in the person of the Cynic Crescens, who was in fact to bring him to trial before the Prefect of the City and to engineer his martyrdom. ${ }^{15}$ Despite the calm and measured tone of both parts of the Apology, and despite Pius' own wishes as expressed in his letter to Asia, there still hung in the air the chance that something unexpected could ignite persecution - an earthquake, some personal grievance, or simple fear of the new and strange.

The accession of Marcus Aurelius was to bring a sharp change in the position of Christianity. As we have seen, Justin, a Christian with a classical education and experience of the chief Greek philosophical schools, argued for his faith as a philosophy in its own right. This was bound to create a defensive reaction, especially under an emperor so deeply under the influence of contemporary Stoicism. In a famous passage of the Meditations, Marcus refers to the Christians' "sheer obstinacy" ( $\psi \iota \lambda$ ì $\pi \alpha \rho \alpha \dot{\tau \alpha} \xi ı)$ in the face of death, and to their failure to present reasons convincing to others. ${ }^{16}$ This does not reveal much about his personal views, except perhaps a contempt for an unreasoning, unphilosophical attitude towards a subject in which he himself was so heavily engaged.

But Marcus the philosopher was a different person from Marcus the emperor, and in that capacity he was faced with several major crises. One was the so-

13. Chadwick, 1967, p. 160: “The first serious beginnings of Christian philosophy appear in Justin Martyr."

14. I do not go into the debated questions of how far this process had already been carried by Philo, especially with his Logos-doctrine, and of the historical point at which "Christianity" comes into existence as an entity distinct from Judaism.

15. Justin., I Apol. 8 (3); Euseb., Hist. eccl. IV 16, 7-9. Crescens: Goulet-Cazé, 1994, p. 510.

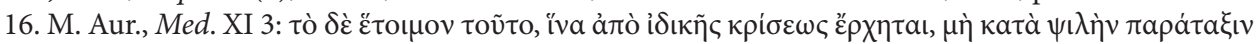

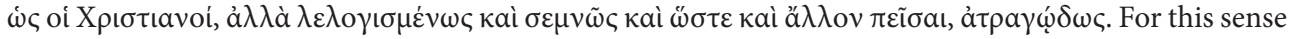
of $\pi \alpha \rho a ́ \tau \alpha \xi ı$, sometimes misunderstood, cf. Aristid. Or. 51, 9, ed. ${ }^{2}$ B. Keil, Berlin, 1958, on his insistence

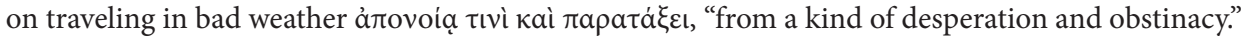


called Antonine Plague, which began about 165 and had a devastating effect on the society and economy of the empire. ${ }^{17}$ Another was the beginning of a series of German incursions into Roman territory, which drew Marcus away from Rome in 169 , and were to keep him on the Danube front for most of his remaining years. In the face of these crises he took religious measures that cannot have been without consequence for his Christian subjects. According to the Historia Augusta, "the Marcomannic war caused so much fear that Antoninus summoned priests from everywhere, performed foreign rites, and purified Rome in every way possible, and was hindered from setting out for war" (tantus timor belli Marcomannici fuit ut undique sacerdotes Antoninus acciverit, peregrinos ritus impleverit, Romam omni genere lustraverit, retardatusque bellica profectione sit). ${ }^{18}$ The biographer continues: "The Plague was so great that bodies were carried out in carts and wagons... [It] carried off many thousands, including many of the leading citizens, to the most prominent of whom Antoninus set up statues" (tanta autem pestilentia fuit, ut vehiculis cadavera sint exportata serracisque... multa quidem milia pestilentia consumpsit multosque ex proceribus, quorum amplissimis Antoninus statuas conlocavit). ${ }^{19}$ The same fears roused by the Plague may explain four altars set up in the Roman forum, inscribed in elegant second-century lettering and dedicated to "The gods that repel

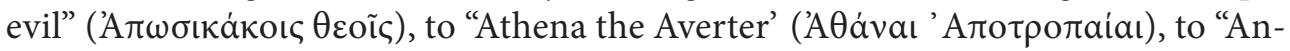

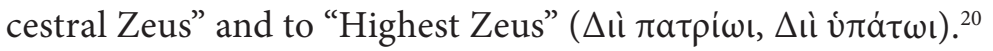

It is unknown whether the same panic in the face of disaster helped to cause the death of Justin in Rome, but that the Christians of Asia faced renewed danger is attested by the apologist Melito. According to him, they had enjoyed comparative peace under Hadrian and Pius, whereas at the time of writing, a prominent Christian in the province, Sagaris by name, had recently been martyred. ${ }^{21}$ Now the "race of the

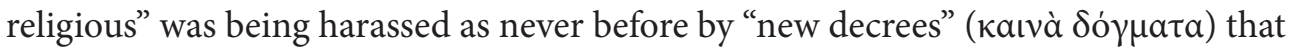
allowed informers (sykophantai) to cheat Christians out of their possessions; if Mar-

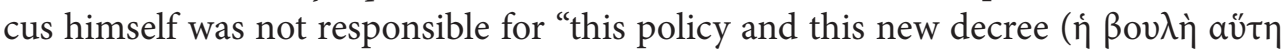

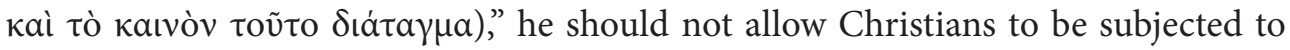

17. Harper, 2007, pp. 98-115.

18. HA, Marc. 13, 1 .

19. HA, Marc.13, 3, 13, 5.

20. IGUR 94-97.

21. Melito names the proconsul as Servilius Paullus, who would have held office about 166-167, cf. Groag, Stein et al., 1933-2015, S 592. Sagaris was bishop of Laodicea, also mentioned at Euseb., Hist. eccl.

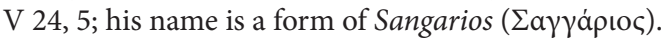


"public plunder" $(\delta \eta \mu \omega \delta \eta \eta \varsigma \lambda \varepsilon \eta \lambda \alpha \sigma i \alpha) .{ }^{22}$ The Apology of Tatian, more an attack on pagan beliefs than a defense of Christianity, perhaps also reflects the fevered atmosphere of persecution under Marcus.

Near the end of the reign, in the year 177, there occurred a persecution of unprecedented savagery in Lugdunum, the capital of Gallia Lugdunensis. This began as an attack on the local Christians by the population, and grew into a campaign led by the governor of the province. Faced by the problem of dealing with Roman citizens who were also Christians, he consulted Marcus, and was instructed to proceed without distinction of rank or status; one Roman citizen, Attalus of Pergamum, was gruesomely tortured and executed. The long, vivid account sent by the Christians of Lugdunum to their brothers in Asia is itself a specimen of early Christian literature, composed by someone with a sure grasp of style and possessing considerable narrative ability. ${ }^{23}$

Yet these same last years of Marcus's reign produced one of the most remarkable of all these early apologies - that of the Athenian Athenagoras. Addressing

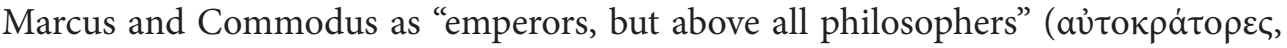

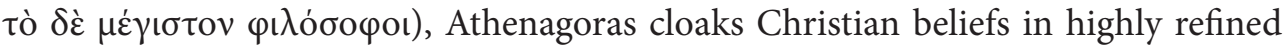
Greek. He defends Christians from the charges of godlessness and disloyalty, and expounds cardinal tenets such as the Trinity and the sonship of Christ, while contriving never to use the words "Christ" or "Jesus", and discreetly introducing quotations of the Founder's words with an indefinite "he says" ( $\varphi \eta \sigma \iota v)$. Athenagoras' treatise On the Resurrection is likewise a learned defense of one of Christianity's most difficult doctrines, conducted at a level of medical and argumentative sophistication that recalls his great contemporary, Galen. ${ }^{24}$

Under the last of the Antonine emperors, Commodus, there is little sign of a policy towards Christianity, and there is also a dearth of known apologists. Certainly martyrdom continued, and two accounts survive, that of the martyrs of Scilli in Africa (the first surviving in Latin), and that of Apollonius, which (if it is not fictional) appears to be set in Asia, but perhaps took place in Rome. To the same reign belongs Tertullian's anecdote of an incident in Asia in which the proconsul, Arrius Antoninus, though conducting a severe persecution, dismissed voluntary martyrs with an invitation to kill themselves if they so wished. ${ }^{25}$

22. Melito in Euseb., Hist. eccl. IV 26, 5-11.

23. Rébillard, 2017, pp. 145-173 (Euseb., Hist. eccl. V 1-4).

24. Athenagoras: Quasten, 1950, pp. 29-36; Keseling, 1950, pp. 881-888. Apology: Pouderon, 2006.

25. Scillitan martyrs: Rébillard, 2017, pp. 351-359. Apollonius: Musurillo, 1972, no. 7, pp. 90-105, on the text tradition, Rébillard, 2017, p. 31. Arrius Antoninus (Groag, Stein et al., 1933-2015, A 1088): Tert., Scap. V 1, Dekkers, 1954, pp. 1131-1132: Arrius Antoninus in Asia cum persequeretur instanter, omnes 
The combined evidence suggests that persecution at the local level continued sporadically during the Antonine period, as it did later. Hadrian and Antoninus Pius, when called upon for guidance, tended to check attacks on Christians that did not follow the accepted legal forms, though leaving an ample margin of discretion to individual governors. With Marcus there is a visible move towards greater severity, encapsulated in the "new decrees" of which Melito complains. How long this more oppressive policy lasted is impossible to say, and Commodus may have relaxed it. Persecution certainly continued in Africa under the Severans, but the same period also saw Christians such as Julius Africanus holding positions of responsibility in Rome. An inscription carved discreetly and posthumously on a Roman sarcophagus shows that the deceased, M. Aurelius Prosenes, was both a Christian and a trusted freedman of Caracalla. ${ }^{26}$

While the development of apologetics is in part the result of developments internal to Christianity, it also owes something to external and contingent factors, of which two may be singled out.

This was an age in which education (paideia) enjoyed unprecedented prestige. The "second or new Sophistic" chronicled by Philostratus now produced its most conspicuous representative, Herodes Atticus, whose interests included philosophy as well as rhetoric. He was also acquainted with Galen, as an Arabic translation of one of his works has revealed. ${ }^{27}$ Galen was the greatest doctor of his day, and he too had a deep interest in philosophy, which he thought an essential part of the doctor's preparation. It is thus in accordance with the spirit of the times, as well as Christianity's own internal dynamic, that its defenders begin to present it as a philosophy, and that they appeal to the emperors as philosophers and as "lovers of culture."

Judaism had for many centuries attracted the curiosity of Greek observers, among whom it sometimes incurred hostility, as with Apion of Alexandria, while at other times it attracted adherents or at least sympathetic interest, as it did with a pupil of Herodes Atticus. ${ }^{28}$ But the Jewish revolts under Trajan and Hadrian not only caused immense destruction, the expulsion of Jews from Jerusalem, and its refoun-

illius civitatis Christiani ante tribunalia eius se manu facta obtulerunt: tum ille paucis duci iussis reliquis

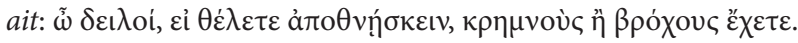

26. Africanus: Adler, 2009, pp. 1-15. Prosenes: CIL VI $8498=$ ILS 1738. On Caracalla and the Christians, Straub, 1954, pp. 898-900.

27. Galen, On examinations by which the best physicians are recognized, ed. Iskandar, 1988, pp. 113115 .

28. Robert, 1978, pp. 245-252 = Robert, 1989, pp. 701-708, showed that Amphicles of Chalcis, a pupil of Herodes, borrowed phrases from Deuteronomy to protect a bath-house. 
dation as a Roman colony, but also had the effect of accentuating the divide between Christianity and Judaism on which Christians had long insisted. Christianity was now established as a different religion from its parent, and the opposition of the two had serious consequences in real life. Bar Kokhba is said to have persecuted Christians within the areas under his control, and Jews are alleged to have shared in the disturbances that led to the martyrdom of Polycarp. ${ }^{29}$ The same antagonism found its expression in the intellectual debate between Christianity and its critics. In his True Word (Alêthês Logos), the first recorded work to show a Greek intellectual treating Christianity as a subject worthy of refutation, the philosopher Celsus drew on arguments supplied to him by Jewish informants. Justin's Dialog with Trypho is framed as a discussion in which Justin refutes Jewish objections to the new faith. Apologists such as Justin and Athenagoras could now insist that they were loyal subjects who prayed for the stability of the empire and the eternity of the ruling house, ${ }^{30}$ confident that such claims marked a distance between their own "philosophy" and the Judaism from which it had sprung.

Against this changed intellectual background, persecution of Christians continued within the empire, as it did with intermissions long and short until the reign of Constantine. The violence triggered by the events of Marcus' reign recurred on a smaller or a larger scale, notably in the crisis of the mid-third century under Decius. Christians still had to justify and to explain their faith to unbelievers well into the fifth century. But the Antonine period is perhaps the first in which the outlines of a new dispensation emerge. Christianity begins to develop the armature that enabled it to survive the intellectual competition of the later empire, and to transform itself from a religious movement of Jewish dissidents into a philosophy acceptable to educated Greeks and Romans.

29. Bar Kokhba: Justin, I Apol. 31, 7; Justin, Dial. Trypho 110, ed. Otto, 1876; Euseb., Hist. eccl. IV 5, 2; Oros., Hist. VII 13, 4, ed. Zangemeister, 1882. Jews in martyrdom of Polycarp: Rébillard, 2017, pp. 108-143, chs. 12, 13, 17, 18.

30. Justin, I Apol. 17, 3; Athenag., Apol. 37, with Pouderon, 2006, n. 3. 


\section{BibliogRAPHY}

Adler, W. (2009). The Cesti and sophistic culture in the Severan age. In Wallraff and Mecella, 2009, pp. 1-15.

Armstrong, A.H. (ed.) (1967). The Cambridge History of late Greek and early medieval Philosophy. Cambridge: Cambridge University Press.

Bardy, G. (ed.) (1952). Eusèbe de Césarée: Histoire ecclésiastique, Livres I-IV. Sources chrétiennes XXXI. Paris: Éditions du Cerf.

Camelot, P.T. (ed.) $\left(1998^{4}\right)$. Ignace d'Antioche: Lettres. Sources chrétiennes X bis. Paris: Éditions du Cerf.

Chadwick, H. (1967). The beginning of Christian philosophy: Justin: the Gnostics. In Armstrong, 1967, pp. 158-167.

Coleman, K.M. (2008). Exchanging gladiators for an aqueduct at Aphrodisias (SEG 50, 1096). Acta Classica, 51, pp. 31-46.

Dassmann, E. (ed.) (1950). Reallexikon für Antike und Christentum, 1. Stuttgart: Hierseman.

Dassmann, Ernst (ed.) (1954). Reallexikon für Antike und Christentum, 2. Stuttgart: Hierseman.

Desideri, P. and Fontanella, Fr. (eds.) (2013). Elio Aristide e la legittimazione greca dell' impero di Roma. Bologna: Società editrice Il mulino.

Dekkers, E. (1954). Corpus Christianorum, Series Latina, II. Turnholt: Brepols.

Goulet, Richard (ed.) (1994). Dictionaire des philosophes antiques, II. Paris: Éditions du Centre national de la Recherche scientifique.

Goulet-Cazé, M.O. (1994). Crescens. In Goulet, 1994, p. 510.

Groag, E., Stein, A. et al. (eds.) (1933-2015). Prosopographia Imperii Romani. Berlin.

Harper, K. (2007). The Fate of Rome: Climate, Disease and the Fate of an Empire. Princeton and Oxford: Princeton University Press.

Iskandar, A.Z. (1988). Corpus Medicorum Graecorum, Suppl. Or. 4. Berlin.

Jones, C.P. (2013). Elio Aristide e i primi anni di Antonino Pio. In Desideri and Fontanella, 2013, pp. 49-52.

Jones, C.P. (2018). A Letter of Antoninus Pius and an Antonine Rescript concerning Christians. Greek Roman and Byzantine Studies, 58, pp. 67-76.

Keseling, P. (1950). Athenagoras. In Dassmann, 1950, pp. 881-888.

Millar, F. (1977). The Emperor in the Roman World. London: Duckworth.

Munier, C. (ed.) (2006). Justin: Apologie pour les chrétiens. Sources chrétiennes 507. Paris: Cerf.

Musurillo, H.A. (ed.) (1972). The Acts of the Christian Martyrs. Oxford: Clarendon Press

Otto, C.Th. (1876). Corpus Apologetarum Christianorum 1. Jena.

Paulsen, P. (1996.) Reallexikon für Antike und Christentum, XVII. Stuttgart: Hiersemann.

Pouderon, B. et al. (2003). Aristide: Apologie. Sources chrétiennes 470. Paris: Cerf.

Pouderon, B. (2006). Athénagore: Supplique au subject des chrétiens et Sur la résurrection des morts. Sources chrétiennes 379. Paris: Cerf. 
Quasten, J. (1950). Patrology, I: The Beginnings of patristic literature. Utrecht: Sprectrum Publishers.

Rébillard, É. (ed.) (2017). Greek and Latin Narratives about the Ancient Martyrs. Oxford, New York, NY: Oxford University Press.

Robert, L. (1978). Malédictions funéraires grecques. CRAI, 122.2, pp. 241-289.

Robert, L. (1989). Opera Minora Selecta, V. Amsterdam.

Sainte-Croix, G.E.M. (1963). Why were the early Christians persecuted? Past and Present, 26, pp. 6-38, reprinted in Sainte-Croix, Whitby and Streeter, 2006, pp. 105-132.

Sainte-Croix, G.E.M., Whitby, M., Streeter, J. (eds.) (2006). Christian Persecution, Martyrdom and Orthodoxy. Oxford and New York: Oxford University Press.

Straub, J. (1954). Caracalla. In Dassmann, 1954, pp. 893-901.

Wallraff, M. and Mecella, L. (eds.) (2009). Die Kestoi des Julius Africanus and ihre Überlieferung. Berlin and New York: Walter de Gruyter.

Weiss, P. (2008). Die vorbildliche Kaiserehe. Zwei Senatsbeschlüsse beim Tod der älteren und der jüngeren Faustina. Chiron, 38, pp. 1-45.

Zangemeister, C. (1882). Corpus Scriptorum Ecclesiasticorum Latinorum, V. Vienna. 